\title{
Presentation by Concepción Escobar-Hernández
}

\author{
The Relationship between the International Law Commission and the Sixth \\ Committee of the General Assembly: Some Methodological Reflections and \\ Proposals
}

\author{
Member of the International Law Commission
}

\section{Some Introductory Remarks}

The celebration of the seventieth session of the International Law Commission offers an extraordinary opportunity to reflect, once again, upon the relationship between the Commission and the Sixth Committee of the General Assembly. This topic is not new and it is, in itself, an omnipresent element in the collective reflection upon the role to be played by the International Law Commission in the process of building the international legal order.

However, this topic calls for special attention at a moment when the Commission reaches "old age" in an international social environment in which, on the one hand, new organs and fora have emerged with whom to share the task of promoting the progressive development and codification of international law and, on the other hand, where there is a new, ongoing debate on the role of international law in the general framework of international relations, a debate driven to a great extent by the United Nations' objective of strengthening of the rule of law at the national and international levels. From this perspective, one cannot but confirm that the Commission has arrived at this moment in good shape, that in these seven decades it has fulfilled a great deal of its objectives, and that it continues to be at the centre of the international legal system. Nevertheless, it should not be forgotten that the Commission is today facing new challenges and that, in order to confront them, it must internally reflect on multiple issues, among which reconsideration of its working methods and the strengthening of its relationship with the Sixth Committee must be central. Both issues are closely intertwined and this brief contribution is devoted to them.

Indeed, the essential nature of the relationship between the International Law Commission and the Sixth Committee of the General Assembly cannot be put into question, because the fulfilment of one of the mandates given by the Charter of the United Nations to the General Assembly, namely contributing to the promotion of the progressive development of international law and its codification, depends on the existence of a fluent, constructive and efficient relationship between the two bodies. Such a relationship has been in place 
continuously due to their common character as subsidiary organs of the General Assembly, without neglecting their different nature and functions. Thus, whereas the Sixth Committee is an intergovernmental body responsible for implementing that mandate, by debating and making decisions that will later be formally adopted by the General Assembly, the International Law Commission is an expert body responsible for preparing, from a technical and legal perspective, the studies and drafts to be considered by the Sixth Committee at a later stage. Each of these bodies, it is obvious, exercises its functions autonomously, but it is also evident that the effective fulfilment of their respective mandates concerning the progressive development and codification of international law depends on an adequate relationship and interaction between them.

That such relationship and interaction exist is a reality. However, one could wonder whether the current relationship model is satisfactory and whether the best means to attain an effective interaction are being used. To answer these questions, one must first analyze the International Law Commission's own activity and the reaction thereto of the Sixth Committee. This approach necessitates, in particular, not so much a substantive examination of the work of both bodies as it does, above all, an examination of the means and tools they use to entertain an effective relationship. Such means and tools can relate to multiple issues but, for the sake of brevity, I will only refer to those relating to issues of particular relevance, namely: i) the selection of topics to be included in the programme of work of the International Law Commission; ii) the transmission of information (reporting) on the work of the Commission to the Sixth Committee and to States; iii) the contribution of States to the work of the Commission; iv) the holding of meetings between the International Law Commission and the Sixth Committee; and v) the response of the Sixth Committee to the final work of the International Law Commission.

i) Selection of topics. Although some of the first topics of the programme of the International Law Commission were referred to it by the General Assembly, ${ }^{1}$ the use of this way to proceed has been exceptional. On the other hand, even though the statute of the Commission allows States to submit topics directly to the Commission, this possibility has been absent from the practice of the Commission until the current session, when a State proposed the conduct of a study

1 These topics were fundamental rights and duties of States, UNGA Res 178 (II) (21 November 1947); formulation of the Nuremberg Principles, UNGA Res 177 (II) (21 November 1947); a 
on the implications of sea-level rise. ${ }^{2}$ Therefore, the initiative in the selection of topics has been in the hands of the Commission, even though States have made comments (with varying degrees of intensity) on the proposals of topics included in the long-term programme of work. At any rate, this lack of participation of States in the selection of topics has at times resulted, and could result in the future, in an estrangement between the topics that are more interesting for States and the topics actually included in the active program of the Commission.

ii) Report on the work of the International Law Commission. The Commission reports on its work to States and to the Sixth Committee, essentially through the annual report, the reports of the Special Rapporteurs and the summary records of its debates. This is supplemented by the presentation of the annual report by the Chair of the Commission on the occasion of the discussion of the corresponding item on the agenda of the Sixth Committee. A recent addition to this is the audio-recording of the plenary meetings of the Commission, which are available on the conference website of the United Nations Office at Geneva. ${ }^{3}$ Beyond these tools there is no other channel of information relating to the ongoing session and even though States can benefit from the complete information available on the Commission's website, this is not, strictly speaking, a tool permitting the interaction between the International Law Commission and the Sixth Committee. On the other hand, it must also be stressed that there are no formal channels for the Special Rapporteurs to interact with the Sixth Committee, except - when that is possible - on the occasion of their presence in the debates during the International Law Week and the very brief intervention they may make at the end of the debate. This is somehow alleviated by the initiative of the Interactive Dialogue (see below), which is nonetheless very limited in scope.

iii) Contribution of States to the work of the International Law Commission. Substantially speaking, the most important way of interaction between the Commission and the Sixth Committee is the contribution of States to the work of the Commission on each of the topics included in its programme, which essentially takes place along three avenues: a) the declarations during

draft code of crimes against the peace and security of mankind, UNGA Res 177 (II) (21 November 1947); and the question of international criminal jurisdiction, UNGA Res 26 o B (III) (9 December 1948).

2 See statement of the Marshall Islands (on behalf of the Pacific Small Island Developing States), made in the Sixth Committee of the General Assembly under agenda item 81: Report of the International Law Commission on the work of its sixty-ninth session (Cluster II), on 26 October 2017, available at <https://papersmart.unmeetings.org/media2/16154559/marshallislands-on-behalf-of-pacific-small-island-developing-states-.pdf>.

3 UNOG Digital Recordings Portal < https://conf.unog.ch/digitalrecordings/\#>. 
the debate of the Sixth Committee; b) the written answers to the questions annually included in the report of the Commission; and c) the written comments on the different drafts approved in first reading by the Commission. These contributions are essential for the work of the Commission as they give it the possibility of benefiting from a sort of substantive interaction with States regarding each of the topics under its consideration. However, in practice, there is a tendency towards a decrease in the number of State contributions, especially written contributions, both with regard to answers to the questions in chapter three of the annual report and with regard to comments on the drafts adopted on first reading. ${ }^{4}$ Although the reasons for this may be various and difficult to assess, the material difficulties faced by the legal services of States in charge of preparing such answers must be taken into account. This problem is aggravated in the case of States with small legal services. In these cases, one cannot disregard the fact that the increase in the number of questions included in the annual reports, and the simultaneous completion of several topics on first reading, complicate the task of collaborating with the Commission. At any rate, whatever the reasons may be, it must be acknowledged that this tendency deprives the Commission of certain information that cannot always be obtained through other channels and, at the same time, creates an estrangement effect between the Commission and the Sixth Committee that could reduce the effectiveness of their respective work.

iv) Meetings between the International Law Commission and the Sixth Committee. Direct contact between the two bodies only takes place in the framework of the debate of the report of the Commission within the Sixth Committee, and such contact is limited given that the Commission participates in the debate only through its Chair. Although it is increasingly frequent that other members of the Commission, in particular Special Rapporteurs, attend the meetings of the Sixth Committee during the International Law Week, they do so on their own initiative and under no specific mandate of the Sixth Committee. On the other hand, it is also relevant that, as reiterated by members of the Commission and delegates to the Sixth Committee, the debate on the report of the Commission is excessively formal and does not permit real interaction. These shortcomings can somehow be remedied by the Interactive Dialogue that takes place on the occasion of the International Law Week, and by the initiative of a group of delegations (the "Friends of the International Law Commission") that have organized round tables and meetings with members

4 In 2018, for example, the topics which States have commented on received between three and eleven written submissions. 
of the Commission who, for one reason or another, happen to be in New York. Nevertheless, in spite of their great value, these initiatives are not enough. In the first case, only three hours (one afternoon session) are allocated to the Interactive Dialogue, and in the second case, the initiative is informal and limited, essentially reliant on mere opportunity and lacking a systematic character.

v) The response of the Sixth Committee to the final work of the International Law Commission. Since the Commission is a subsidiary organ of the General Assembly, it is clear that how the Sixth Committee reacts to the final product of the work of the Commission is of particular importance. In this regard, it should be stressed, first, that the response of the General Assembly to the drafts submitted by the Commission has been remarkably uneven. Suffice it to recall that there was a first phase when drafts on central topics of international law were completed and then systematically transformed into conventions. Since the completion of this phase, the response of the Sixth Committee has been more modulated. Particularly during the last two decades, decisionmaking on the projects prepared by the Commission has slowed down, which has resulted, in practice, in the lack of transformation of such drafts into treaties. The United Nations Convention on the Jurisdictional Immunity of States and their Property 5 is the last draft to have been transformed into a convention which, moreover, has not entered into force yet. This turnaround in the practice of the General Assembly has taken place essentially after the adoption of the articles on the responsibility of States for internationally wrongful acts, ${ }^{6}$ and has been maintained, with slight variations, to the present day. This change has ushered in an interesting debate on the decline in interest in the work of the Commission on the part of the Sixth Committee and States, and on the loss of relevance of the work itself. The Commission seems to have reacted by replacing draft articles as the principal model for its work, and by progressively reinforcing other models for the final presentation of its works, such as guides to practice, draft conclusions, recommendations or principles, and even studies on a given issue. Although the claim that the work of the Commission has lost interest and relevance cannot be sustained if practice is analyzed in detail, the truth is that this change in the response of the Sixth Committee and States to the final work of the Commission reveals a worrying distance between the approach of the Sixth Committee and that of the Commission to the process of progressive development of international law and its codification. This estrangement is no doubt worthy of serious thought, both from the substantive

5 Adopted 2 December 2004, not yet in force, UNGA Res 59/38 (2 December 2004), annex.

6 See UnGA Res 56/83 (12 December 2001), annex. 
and methodological perspective, on the premise that the existing means and tools of collaboration have apparently not been sufficiently effective.

\section{Envisaging for the Future: Some Thoughts and Proposals}

From this critical analysis of the practice and the means of collaboration used thus far by the International Law Commission and the Sixth Committee, one can derive a set of needs that must be met in order to ensure an effective relationship between both bodies. They can be summarized as follows:

i) To promote active participation of States and the General Assembly in the proposal of new topics to be included in the program of work of the Commission;

ii) To promote new mechanisms that might help to transmit more rapidly and efficiently the work of the Commission to States and to the Sixth Committee, reinforcing the principle of transparency;

iii) To promote methods ensuring that States can actively and substantially contribute to the work of the International Law Commission, in particular enabling a large number of States to overcome the challenges they face due to their level of development, or to their limited operational capacity in legal terms; and

iv) To promote and strengthen an actual, interactive dialogue between the Commission and States in the framework, and under the umbrella, of the Sixth Committee, with a view to encouraging the Commission to take into account the concerns and legitimate interests of States while preserving its technical autonomy.

Meeting these needs would constitute an effective way of contributing to the reinforcement of cooperation and mutual trust between the International Law Commission and the Sixth Committee, and it would enable both bodies to better fulfil their respective mandates with regard to the progressive development and codification of international law. This last objective is of particular importance at present, given that the needs and interests of States are undergoing significant changes that require consistent and systematic legal responses, which the Commission is in a fairly good position to offer.

However, attaining these objectives and providing an effective response to the previous list of needs can only take place through the use of useful mechanisms and working methods that reinforce the actual interaction between the Commission and the Sixth Committee. The existing mechanisms have already been mentioned and, although their limits and shortcomings have been laid bare, it must be recognized that they have made a remarkable contribution 
to the interaction between the two bodies through the years. Keeping and improving them must therefore be the starting point for establishing any future model of relationship and cooperation. Nevertheless, practice has shown that they do not suffice for ensuring a fluent, interactive relationship, so it could be useful to explore new ways to enable the two bodies to deepen their relationship and somehow remedy the shortcomings detected in the current mechanisms. With that in mind, two suggestions aimed at facilitating a more efficient flow of information between the Commission and Member States and at favouring a more intense, interactive debate could be made at this juncture:

i) A collaborative space on the website of the Commission. The website of the Commission has been remarkably improved in recent years, an achievement for which the Codification Division must be complimented. Its content and structure, extremely comprehensive, continues to follow the pattern of an informative site. Since this website is by now consolidated, it would be possible to explore the chance of opening a "collaborative space" on the site, modelled on those already existing on other websites of other international bodies specialized in international law (see, for example, the website of the Committee of Legal Advisers on Public International Law of the Council of Europe (CAHDI)). ${ }^{7}$ This could lead to the creation of a tool for communication between States, the Commission and the Secretariat that would enable them to share information, observations and comments in a direct, flexible manner, as well as receive proposals on issues of interest to States. This flexible formula could expedite communication between States and the Commission, extend it all through the year, and facilitate the participation of States lacking the capacity to submit written comments but able to provide the Commission with information in a simpler, more direct manner.

ii) Topical workshops. One of the principal demands on the part of the delegates of the Sixth Committee is to increase direct contact with the International Law Commission, which has materialized in the request that the Commission meet in New York for the first part of its seventieth session. Although holding the sessions in New York does not automatically result in greater participation of the legal advisers of the Missions in the meetings of the Commission, the experience of the seventieth session, during which the Commission has held part of the meetings in New York, is a good example of how interaction between members of the Commission and delegates can be reinforced, especially through the open "side events" model. This experience is no doubt remarkable, but it does not permit the Commission and the

7 See $<$ https://www.coe.int/en/web/cahdi $>$. 
legal advisers to discuss in-depth, and in an interactive fashion, the topics on which the Commission is working. This concern could be addressed by convening topical workshops, dedicated to specific items on the Commission's programme of work. For them to be effective, workshops should last no longer than a week, they could be scheduled to take place during weeks of less intense work in New York, and they should be formally included in the programme of the General Assembly. The programme of the workshops could be agreed upon by the Chair of the Commission and the Chair of the Sixth Committee, with the support of the Secretariat.

These two methodological proposals require that changes be introduced in the working methods of the Commission and the Sixth Committee and, as a result, their practical value needs to be studied. Nevertheless, adding this new approach to the consolidated working and collaborating methods may result in a remarkable improvement in the relations between the International Law Commission and the Sixth Committee, thus contributing to fulfil the mandate to promote international law given to both bodies.

I am certain that both the International Law Commission and the Sixth Committee will benefit from a debate on these and other methodological issues in the coming years 